\title{
FRACTIONATION OF THE HUMUS OF SOME CHERNOZEMIC SOILS OF SOUTHERN ALBERTA ${ }^{1}$
}

\author{
J. F. Dormaar \\ Research Station, Canada Department of Agriculture, Letbbridge, Alberta
}

Received September 5, 1963

\begin{abstract}
Two orthic profiles, widely separated geographically, of each of four parent materials-lacustrine, alluvial-lacustrine, glacial till, and aeolian-were selected at undisturbed sites within each of the Brown, Dark Brown, and Thin Black soil zones. Material from the $\mathrm{Ah}$ and $\mathrm{Bm}$ horizons was subjected to solvent extraction, and for each sample the total organic carbon of seven different fractions was determined.

The efficiency of the procedure in extracting humus carbon decreased as the total carbon content of the soil increased. Total organic matter, the first humic acid fraction, and the combined total of the three humic acid fractions showed significant differences between soil zones. The only significant separation between all four parent materials was made by the alcohol-benzene fraction. Other parent material separations were possible only following the summation of data of several fractions, such as the three humic acid fractions or the two fulvic acid fractions. A simplification of the procedure in case of soils of one Order and a modification to overcome the impeding effect of increased carbon content are requisite.
\end{abstract}

\section{INTRODUCTION}

Chernozemic soils are found on various parent materials (14), yet morphologically similar soils may still differ in the nature of their humus complex. The effect of the composition of parent materials on soil formation has been shown $(1,6,13)$ : for example, solonetzic and chernozemic soils occur side by side within the same soil zone. Further, parent material has been found to correlate with certain grass species $(4,5,7)$, which in turn could lead to qualitative differences of the soil organic matter.

Differential-extraction methods that are supposed to give an indication of the state of combination of humic substances in the soil have been devised by Russian soil scientists (10). It should be realized, however, that the fractionation of the organic matter is to some extent arbitrary since the fractions are closely interconnected by transitional forms. The purpose of this study was to determine if a procedure currently in use in the U.S.S.R. for fractionating soil humus could separate chernozemic soils of southern Alberta by soil zone and parent material on the basis of the soil humus.

\section{MATERIALS AND METHODS}

Two profiles, widely separated geographically, of each of four parent materials-lacustrine, alluvial-lacustrine, glacial till, and aeolian-were selected at undisturbed sites within each of the Brown, Dark Brown, and Thin Black soil zones. The soil series sampled were all members of the orthic subgroups of the Brown, Dark Brown, and Black Great Groups of the Chernozemic Order (Table 1). Samples were taken from the central part of each of the $\mathrm{Ah}$ and $\mathrm{Bm}$ horizons. Each sample was air-dried and ground to pass a 60 -mesh sieve.

The humus was fractionated by a procedure originally devised by Tyurin (16) and subsequently modified by Kononova and co-workers $(8,9,10,11)$. For convenience, the method of fractionation is shown in flow-sheet form.

${ }^{1}$ Presented before Canadian Society of Soil Science, Banff, Alta., June, 1963.

Can. J. Soil Sci. Vol. 44 (1964) 


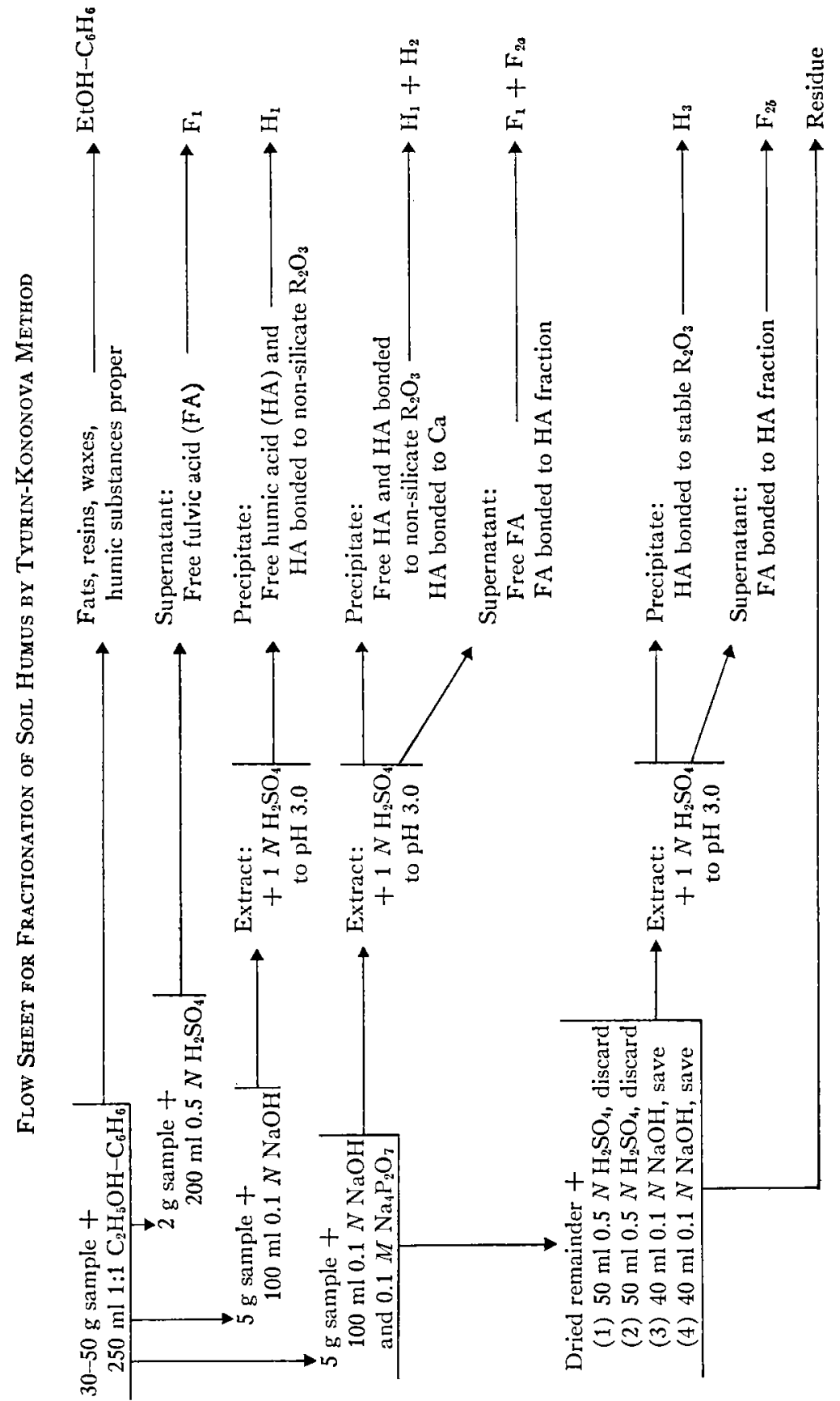


Table 1. Description of solls from southern Alberta

\begin{tabular}{clll}
\hline Zone & Parent material & \multicolumn{1}{c}{ Series } & \multicolumn{1}{c}{ Texture } \\
\hline Brown & Lacustrine & Seven Persons & Silt loam \\
& Alluvial-lacustrine & Chin & Silt loam \\
& Sorted till & Foremost & Loam \\
& Aeolian & Cavendish & Loamy fine sand \\
Dark Brown & Lacustrine & Coaldale & Silty clay loam \\
& Alluvial-lacustrine & Lethbridge & Loam \\
& Sorted till & Readymade & Loam \\
& Aeolian & Carmangay & Very fine sandy loam \\
Thin Black & Lacustrine & Pincher & Clay \\
& Alluvial-lacustrine & Stand Off & Silty clay loam \\
& Till & Leavitt & Loam \\
& Aeolian & Irma & Medium sand \\
\hline
\end{tabular}

Total organic carbon of the soils was determined by difference between total carbon (3) and inorganic carbon (2). The carbon content of the various fractions was determined by the procedure of Allison (2). Mechanical analyses were carried out according to a modified procedure for pipette analyses (15).

\section{RESULTS AND DISCUSSION}

Total organic carbon values increased significantly (at $5 \%$ level) in both the $\mathrm{Ah}$ and $\mathrm{Bm}$ horizons from the Brown to the Thin Black soil zone for each parent material except the aeolian sample (Table 2). No adequate explanation can be given as yet for the low carbon content of the Irma medium sand. Within each zone the aeolian parent material contained significantly less total organic carbon than the other three parent materials. Only in the Thin Black soil zone did the till soil contain significantly more organic carbon than the soils formed from lacustrine and alluvial-lacustrine parent materials.

The $\mathrm{H}_{1}$ fraction and the combined total of the three humic acid fractions $\left(\mathrm{H}_{1}+\mathrm{H}_{2}+\mathrm{H}_{3}\right)$ also showed significant differences between zones (Table 3). Although the carbon content of all the other fractions increased going from the Brown to the Thin Black soil zone, these differences were not significant.

The recovery of organic carbon proved to be complete for both horizons of all soils. However, the amount of organic carbon in the soil residue increased as the total carbon content of the soil increased. This indicates that this extraction procedure is not satisfactory. Modifications seem necessary to overcome this effect of increased carbon content.

Table 2. Per cent total organic carbon of chernozemic solls of southern Alberta (AVERAGE OF TWO PROFILES EACH ANALYSED IN DUPLICATE)

\begin{tabular}{lcccccc}
\hline \multicolumn{1}{c}{ Zone: } & \multicolumn{2}{c}{ Brown } & \multicolumn{2}{c}{ Dark Brown } & \multicolumn{2}{c}{ Thin Black } \\
\hline \multicolumn{1}{c}{ Horizon: } & Ah & Bm & Ah & Bm & Ah & Bm \\
\hline Lacustrine & 2.27 & 1.24 & 3.98 & 2.01 & 5.73 & 2.55 \\
AlluviaI-lacustrine & 2.75 & 1.31 & 4.01 & 2.33 & 5.14 & 2.57 \\
Till & 2.95 & 1.37 & 4.06 & 2.35 & 7.50 & 3.42 \\
Aeolian & 1.45 & 0.753 & 3.04 & 0.889 & 1.98 & 0.648 \\
Average for zone & 2.36 & 1.17 & 3.77 & 1.89 & 5.09 & 2.30 \\
\hline
\end{tabular}


The carbon left in the residue was about the same for the lacustrine, alluvial-lacustrine, and till materials (Table 4). A smaller percentage was left in the residue of the acolian soils. This was true for both the $\mathrm{Ah}$ and $\mathrm{Bm}$ horizons. Similar patterns were obtained for the soils of the Dark Brown and Thin Black soil zones, and, therefore, the data for these zones are not presented.

With two exceptions, the carbon contents of the various fractions of the till, lacustrine, and alluvial-lacustrine soils did not differ, but these contents were significantly larger than those of the aeolian soils. The $\mathrm{H}_{\mathbf{1}}$ fraction did not make this separation, whereas the EtOH- $\mathrm{C}_{3} \mathrm{H}_{6}$ fraction separated all four parent materials. The group of substances extracted by the EtOH- $\mathrm{C}_{6} \mathrm{H}_{6}$ chiefly includes oils and fats, long-chain fatty acids, and alcohols. Although these are inherent constituents of plant residues and microbial cells, Kosaka and co-workers (12) feel that this material is produced in the process of humification. For the entire $\mathrm{H}\left(\mathrm{H}_{1}+\mathrm{H}_{2}+\mathrm{H}_{3}\right)$ and $\mathrm{F}\left(\mathrm{F}_{1}+\mathrm{F}_{2}\right)$ fractions of both horizons the carbon content of the till was significantly larger than those of the lacustrine and alluvial-lacustrine soils. These in turn were significantly larger than that of the aeolian soils.

One Order of soils was studied and, therefore, large differences within the various fractions could not be expected. Parent material has been found to correlate with certain grass species, and it could therefore be postulated that

TABLE 3. CARBon OF VARIOUS hUMUS FRaCTIONS EXPRESSED AS PERCENTAGE OF TOTAL ORGANiC CARBON OF SOIL (AVERAGE OF EIGHT PROFILES EACH ANALYSED IN DUPLICATE)

\begin{tabular}{lrrrrrr}
\hline \multicolumn{1}{c}{ Zone: } & \multicolumn{2}{c}{ Brown } & \multicolumn{2}{c}{ Dark Brown } & \multicolumn{2}{c}{ Thin Black } \\
\hline \multicolumn{1}{c}{ Horizon: } & \multicolumn{1}{c}{$\mathrm{Ah}$} & \multicolumn{1}{c}{$\mathrm{Bm}$} & \multicolumn{1}{c}{$\mathrm{Ah}$} & \multicolumn{1}{c}{$\mathrm{Bm}$} & $\mathrm{Ah}$ & $\mathrm{Bm}$ \\
\hline EtOH-C $_{6} \mathrm{H}_{6}$ & 6.7 & 4.6 & 4.3 & 3.5 & 3.4 & 3.1 \\
$\mathrm{H}_{1}$ & 6.7 & 5.3 & 6.5 & 4.5 & 8.1 & 5.3 \\
$\mathrm{H}_{2}$ & 13.9 & 24.4 & 9.1 & 15.6 & 8.2 & 14.0 \\
$\mathrm{H}_{3}$ & 4.6 & 7.9 & 4.0 & 5.3 & 3.3 & 5.1 \\
$\mathrm{~F}_{1}$ & 6.8 & 9.1 & 5.6 & 8.3 & 4.2 & 7.7 \\
$\mathrm{~F}_{2}$ & 24.2 & 35.0 & 17.2 & 23.0 & 12.7 & 13.8 \\
Residue & 35.4 & 16.6 & 53.8 & 39.1 & 61.9 & 50.9 \\
\% recovery & 98.3 & 102.6 & 100.5 & 99.5 & 101.8 & 100.0 \\
\hline
\end{tabular}

Table 4. Carbon of various humus fractions within a zone, expressed as percentage OF TOTAL ORGANIC CARBON OF SOIL (AVERAGE OF TWO PROFILES AND DUPLICATE ANALYSES)

\begin{tabular}{|c|c|c|c|c|c|c|c|c|}
\hline \multirow{2}{*}{$\frac{\text { Zone: }}{\text { Horizon: }}$} & \multicolumn{8}{|c|}{ Brown } \\
\hline & & $\mathrm{Ah}$ & & & & $\mathrm{B}_{\mathrm{n}}$ & & \\
\hline $\begin{array}{l}\text { Parent } \\
\text { material: }\end{array}$ & $\begin{array}{l}\text { Lacus- } \\
\text { trine }\end{array}$ & $\begin{array}{l}\text { Alluvial- } \\
\text { lacustrine }\end{array}$ & Till & Aeolian & $\begin{array}{l}\text { Lacus- } \\
\text { trine }\end{array}$ & $\begin{array}{l}\text { Alluvial- } \\
\text { lacustrine }\end{array}$ & Till & Aeolian \\
\hline $\begin{array}{l}\mathrm{EtOH}-\mathrm{C}_{6} \mathrm{H}_{6} \\
\mathrm{H}_{1} \\
\mathrm{H}_{2} \\
\mathrm{H}_{3} \\
\mathrm{~F}_{1} \\
\mathrm{~F}_{2} \\
\text { Residue }\end{array}$ & $\begin{array}{r}8.0 \\
4.5 \\
10.7 \\
5.4 \\
7.8 \\
27.8 \\
38.5\end{array}$ & $\begin{array}{r}5.9 \\
4.9 \\
13.7 \\
3.6 \\
7.5 \\
21.1 \\
39.6\end{array}$ & $\begin{array}{r}4.9 \\
6.8 \\
17.0 \\
5.2 \\
5.0 \\
21.9 \\
37.3\end{array}$ & $\begin{array}{r}9.9 \\
13.0 \\
13.3 \\
4.2 \\
7.7 \\
29.4 \\
23.7\end{array}$ & $\begin{array}{r}3.7 \\
4.5 \\
24.0 \\
7.5 \\
9.6 \\
29.2 \\
21.1\end{array}$ & $\begin{array}{r}4.6 \\
3.6 \\
21.8 \\
8.5 \\
8.4 \\
33.9 \\
22.3\end{array}$ & $\begin{array}{r}4.8 \\
5.0 \\
24.8 \\
8.3 \\
7.7 \\
38.3 \\
18.3\end{array}$ & $\begin{array}{r}6.2 \\
10.0 \\
28.7 \\
6.7 \\
12.5 \\
34.8 \\
3.3\end{array}$ \\
\hline
\end{tabular}


certain qualitative and quantitative carbon differences do exist between soils formed from various parent materials. Most fractions did not show this. The summation of data of several fractions did give significant differences. A simpler procedure may be requisite in order to show the effect, either direct or indirect, of parent material on soil carbon.

\section{ACKNOWLEDGEMENTS}

I wish to express my sincere appreciation to T. W. Peters, Pedologist, Alberta Soil Survey, Research Branch, Canada Department of Agriculture, Edmonton, for his assistance in collecting the soil samples, which produced a good duplication of profiles.

Reference 9 was kindly supplied by M. M. Kononova, V. V. Dokuchayev Soil Institute, Moscow, U.S.S.R., and thanks are due to A. Tron of this Station for the translation of this reference.

\section{REFERENCES}

1. Albareda, J. M. 1955. Chemisches Studium vom Humus verschiedener Bodentypen in Spanien. Z. Pflanzenernähr., Düng., Bodenk. 69(114), 86-93.

2. Allison, L. E. 1960. Wet-combustion apparatus and procedure for organic and inorganic carbon in soil. Soil Sci. Soc. Am. Proc. 24, 36-40.

3. Association of Offictal Agricultural Chemists. 1955. Official and tentative methods of analysis. 8th ed. Washington, D.C.

4. Coupland, R. T. 1950. Ecology of mixed prairie in Canada. Ecol. Monographs, 20, $272-315$.

5. Coupland, R. T. 1961. A reconsideration of grassland classification in the northern great plains of North America. J. Ecology, 49, 135-167.

6. EhrLich, W. A., H. M. Rice, and J. H. Ellis. 1955. Influence of the composition of parent materials on soil formation in Manitoba. Can. J. Agr. Sci. 35, 407-421.

7. Hubbard, W. A. 1950. The climate, soils, and soil-plant relationships of an area in southwestern Saskatchewan. Sci. Agr. 30, 327-342.

8. Kononova, M. M. 1961. Soil organic matter. Pergamon Press, New York.

9. Kononova, M. M. 1961. Rapid determination of the humus composition of mineral soils (Application of sodium pyrophosphate for extraction of humic substances). V. V. Dokuchayev Soil Inst., Acad. Sci., U.S.S.R.

10. Kononova, M. M., and N. P. Bel'chinova. 1961. Quick methods of determining the humus composition of mineral soils. Pochvovedenie, 1961(10), 75-87.

11. Kononova, M. M., N. P. Bel'chikova, and I. V. Aleksandrova. 1960. Conference on methods of studying humus. Pochvovedenie, 1960(11), 110-112.

12. Kosaka, J., C. Honda, and A. Izekr. 1961. Fractionation of humic acid by organic solvents. Soil Sci. Plant Nutrition (Tokyo), 7, 48-53.

13. Mitchell, J., H. C. Moss, and J. S. Clayton. 1944. Soil survey of southern Saskatchewan, Rept. No. 12, Univ. of Saskatchewan, Saskatoon, Sask.

14. Rerszig, H. 1956. Charakterisierung der Humuskomponente von Schwarzerden verschiedener Herkunft. Z. Pflanzenernähr., Düng., Bodenk. 74(119), 112-127.

15. Toogoon, J. A., and T.W. Peters. 1953. Comparison of mechanical analysis of soils. Can. J. Agr. Sci. 33, 159-171.

16. Tyurin, I. V. 1951. Method of analysis for the comparative study of soil humus composition. Trudy Pochvennogo Inst. im. V. V. Dokuchaeva, Akad. Nauk S.S.S.R. 38, 5-21. (Chem. Abstr. 47, 5597b. (1953).) 